\title{
A INVENÇÃO DO TRIBUNAL DO JÚRI EM ‘AUTO DA COMPADECIDA” DE ARIANO SUASSUNA
}

\author{
THE INVENTION OF THE JURY IN " THE AUTO MARY " BY ARIANO \\ SUASSUNA
}

${ }^{1}$ Ezilda Claudia de Melo

\section{RESUMO}

Identificou-se as intersecções entre o Tribunal do Júri e a Literatura, no "Auto da Compadecida" de Ariano Suassuna. Enveredou-se num campo de intersecção entre o Direito e a Arte Literária para identificar os personagens, o ritual e a emoção no espetáculo do Tribunal do Júri por ele apresentado. O julgamento é a verdadeira chave para compreensão desta obra e é o ponto de intersecção, nesta pesquisa, com o Direito, pois se pretende relacionar a instituição do Tribunal do Júri a partir das construções de Ariano Suassuna. Concluiu-se que a emotividade dá-se na racionalidade do Tribunal do Júri.

Palavras-chave: Tribunal do júri, Auto da compadecida, Ariano suassuna, Direito e literatura

\begin{abstract}
It identified the intersections between the jury and literature, the "Auto da Compadecida " Ariano Suassuna. He embarked at the intersection field between law and Literary Arts to identify the characters, ritual and emotion in the jury of the show presented by him . The trial is the real key to understanding this work and is the intersection point of this research, with the law as it is intended to relate the institution of the jury from the buildings Ariano Suassuna . It was concluded that emotionality gives on the rationality of the jury.
\end{abstract}

Keywords: Jury court, Auto compadecida, Ariano suassuna, Law and literature

\footnotetext{
${ }^{1}$ Mestra em Direito Público pela Universidade Federal da Bahia - UFBA, Bahia (Brasil).

E-mail: ezildamelo@gmail.com
} 


\section{INTRODUÇÃO:}

O melhor drama está no espectador e não no palco. Machado de Assis ${ }^{1}$

A arte tem muito a dizer ao Direito, em razão da sua complexa compreensão do mundo. Além de Kafka nas palavras de Posner $^{2}$, não foram poucos os grandes literatos da humanidade que tiveram formação jurídica, a exemplo de Balzac, Flaubert, Tolstoi e Goethe, e que trouxeram para o tema de suas obras as questões de Direito. No Brasil, também temos exemplos de escritores que trouxeram para as páginas de suas obras, a discussão jurídica, não no sentido dogmático que geralmente o Direito possui, mas numa compreensão estética, reflexiva, filosófica e profunda que os temas da existência possuem. Nesta linha de entendimento, optou-se por escolher a contribuição de Ariano Suassuna para o Direito, nas apresentações que ele faz sobre o Tribunal do Júri.

Ariano Suassuna com sua imensa capacidade literária enriqueceu a Literatura e o Teatro Brasileiro ao apresentar para a comunidade obras como A Pena e a Lei e Auto da Compadecida. Tem mais de jurídico nas obras de Ariano Suassuna do que em muitas obras que tratam hipoteticamente, na linha kantiana, fechada e hermética, do sistema jurídico. Nesta diretriz também pensa $\mathrm{Streck}^{3}$ ao dizer "não tenho dúvida de que a literatura pode ensinar muito ao direito. Faltam grandes narrativas ao direito. A literatura pode humanizar o direito".

Em Auto da Compadecida, uma obra escrita para o teatro, o cenário é o do sertão das caatingas, a construção de destaque é a igreja, tem-se uma aproximação com os autos de Gil Vicente ${ }^{4}$ de acordo com Tabosa ${ }^{5}$ porque nas duas recria-se o cotidiano das classes sociais, e há também uma aproximação com o teatro espanhol do século

\footnotetext{
${ }^{1}$ ASSIS, Machado de. Papéis Avulsos. São Paulo: Martin, Claret, 2007. p. 76.

${ }^{2}$ POSNER, Richard A. Law and Literature. Cambridge: Harvard University Press, 1988. p. 4.

${ }^{3}$ STRECK, Lenio Luiz; KARAM TRINDADE, André. Direito e Literatura. São Paulo: Atlas, 2013.p. 227.

${ }^{4}$ PRADO, Daniel Nicory do. Autos da Barca do Inferno: o discurso narrativo dos participantes da prisão em flagrante. 2009. 128 f. Dissertação (Mestrado em Direito Público) - Universidade Federal da Bahia, Salvador, 2009. Disponível em: 〈https://repositorio.ufba.br/ri/bitstream/ri/10786/1/Prado.pdf>. Acesso em: 14 ago. 2014.

${ }^{5}$ TABOSA, Leila Maria de Araújo. Carnavalização e Dramaturgia: Gil Vicente e Ariano Suassuna. Disponível em: <www.sbpcnet.org.br/livro/.../resumo_3533.html>. Acesso em:18 ago. 2014. "A carnavalização permite a união de valores antagônicos, combinando-os: o sagrado com o profano, o grandioso com o insignificante; a aproximação de heróis, mitos, personagens históricos da nossa realidade: há em nosso convívio diário, uma aproximação familiar com seres, antes inatingíveis; não se baseia em lendas e nem se consagra através delas, mas sim na fantasia livre e, na maior parte dos casos, o tratamento a lendas e mitos é crítico".
} 
XVII $^{6}$ e semelhanças com a commediadella'arte ${ }^{7}$ que, nas palavras de Freitas, foram construídas sobre bases teatrais não canônicas e extraliterárias e com grande repercussão popular, tanto na concepção dos personagens, quanto também no desenvolvimento da ação. Suassuna teve influência ${ }^{8}$ também de Plauto, Brueghel, Molière, Bosch, Shakespeare, Goya, Cervantes, como também ${ }^{9}$ de Calderon de La Barca, dos artistas coloniais, dos cordelistas a exemplo de Leandro Gomes de Barros. Recebeu muita influência ainda do romanceiro nordestino, por exemplo, $O$ Castigo da Soberba, O Enterro do Cachorro e A História do Cavalo que Defecava Dinheiro, são romances populares anônimos que serviram de inspiração em cenas importantes de Auto da Compadecida.

Neste artigo os objetivos são: explanar a construção dos personagens da obra Auto da Compadecida, analisando como é a formação do Tribunal do Júri ficcional apresentado por Suassuna, e neste sentido observar as semelhanças e diferenças com a instituição do Tribunal do Júri "real".

Metodologicamente, a peça Auto da Compadecida divide-se em três núcleos centrais: a primeira parte é o enterro do cachorro; a segunda é o retorno do Bispo e do Padre com o Major Antonio Morais, e a terceira parte, a que é mais importante para a análise jurídica: é a cena do julgamento. Para Morais da Rosa ${ }^{10}$, o processo penal é para os atores jurídicos diretamente vinculados (juiz, promotor de justiça, advogados, técnicos), e principalmente para os acusados e vítimas -, uma grande interrogação. Em Auto da Compadecida apesar de antecipadamente saber-se que haverá um julgamento e que "A Compadecida" intervirá para salvar os condenados, não se sabe previamente o

\footnotetext{
${ }^{6}$ SUASSUNA, Ariano. O Movimento Regionalista e o Armorial. Folha de São Paulo, São Paulo, 2000. Disponível em: <http://www1.folha.uol.com.br/fsp/ilustrad/fq0409200022.htm>. Acesso em:16 ago. 2014. "E, no meu teatro, por influência de Gil Vicente, do teatro do Século de Ouro espanhol, do Barroco e do Romanceiro Popular Brasileiro, havia um elemento mágico e poético que me afastava dos regionalistas".

${ }^{7}$ FREITAS, Nanci de. A comedia dellaeearte:máscaras, duplicidade e o riso diabólico de Arlequim. Textos escolhidos de cultura e arte populares, Rio de Janeiro, v. 5, n. 1, p. 65-74, 2008.Disponível em: <http://www.tecap.uerj.br/pdf/v5/nanci_de_freitas.pdf>. Acesso em:18 ago. 2014.p. 66. “A comedia della'arte italiana, construída sobre bases teatrais não-canônicas e extraliterárias, alcançaria enorme repercussão popular, estabelecendo um paralelismo importante em relação ao teatro oficial, transformando as páaticas teatrais europeias".

${ }^{8}$ SUASSUNA, Ariano. O Movimento Regionalista e o Armorial. Folha de São Paulo, São Paulo, 2000. Disponível em: 〈http://www1.folha.uol.com.br/fsp/ilustrad/fq0409200022.htm>. Acesso em:16 ago. 2014.

${ }^{9}$ SUASSUNA, Ariano. Após 10 anos afastado da literatura, o autor de "Auto da Compadecida" está escrevendo novo livro. Folha de São Paulo, São Paulo, 26 out. 1991. Entrevista. Disponível em:<http://almanaque.folha.uol.com.br/leituras_16jun00.htm>. Acesso em:8 ago. 2014.

${ }^{10}$ MORAIS DA ROSA, Alexandre. Kafka no processo e na colônia penal. In: LENIO Luiz Streck; TRINDADE, André Karam (Orgs.). Direito e Literatura. São Paulo: Atlas, 2013. p. 9-13. p. 10.
} 
que ocorrerá porque as cenas ainda não ocorreram e estão mescladas a um caos existencialista, nas quais o porvir não obedece a uma lógica previamente dada e, nestas, a emoção é a tônica dos personagens, portanto a grande interrogação que a obra permite.

\section{DESENVOLVIMENTO DA PESQUISA:}

Camus $^{11}$ escreve que o objetivo de um escritor é reencontrar, pelos desvios da arte, as duas ou três imagens simples e grandes às quais o coração se abriu uma primeira vez. Neste sentido, a arte literária é o campo em que as emoções se reconstroem, é o campo em que transdisciplinarmente buscam-se elementos para uma interpretação do instituto jurídico do Tribunal do Júri, pois, diante da percepção de que o fenômeno jurídico é complexo, exige-se que o olhar sobre ele seja ampliado e integrado num sentido transcendente e transgressor, nas palavras de Pinto Neto ${ }^{12}$.

Vem da interligação entre Direito e Arte o motivo da escolha da obra Auto da Compadecida de Ariano Suassuna. O julgamento é a verdadeira chave para compreensão de ambas as obras e é o ponto de intersecção, nesta pesquisa, com o Direito, pois se pretende relacionar a instituição do Tribunal do Júri a partir das construções de Ariano Suassuna.

Para Derrida ${ }^{13}$, o teatro não é uma representação; éa própria vida no que ela tem de irrepresentável. A vida é a origem não representável da representação. Esta vida carrega o homem, mas não é em primeiro lugar a vida do homem, já que este não passa de uma representação da vida e tal é o limite da metafísica do teatro como repetição daquilo que não se repete, o teatro como repetição originária da diferença no conflito das forças, em que o mal é a lei permanente. Para Derrida, pensar o fechamento da

\footnotetext{
${ }^{11}$ CAMUS, Albert. O avesso e o direito. São Paulo: Record. 1995.

${ }^{12}$ PINTO NETO, Moysés da Fontoura. O que significa pensar a transdisciplinaridade? Os fundamentos éticos do dencontro disciplinas. Disponível em: <http://www3.mackenzie.br/editora/index.php/tint/article/viewFile

/2137/1487>. Acesso em: 19 ago. 2014. p.30-31. "Um fenômeno complexo não exige apenas que o olhar de uma disciplina seja ampliado, tampouco que uma gama de conhecimentos em separado possa se unir para compreender, em uma soma de enfoques, o fenômeno. A complexidade exige, sobretudo, um olhar integrado, porém em um sentido bem específico: transcendente, transgressor. É preciso que o prefixo trans supere as disciplinas para além da adição da multidisciplinaridade: saberes não apenas conectados, mas misturados, miscigenados em que a transgressão da disciplina, a trans-disciplina-ridade, possa compreender os fenômenos sem o limite disciplinar. Antes, transgredindo-o. Como se fossem camadas de saber, mas sobretudo por conceitos intrusivos como alteridade, que deixam em suspenso todos os conhecimentos então adquiridos e ameaçam o equilíbrio disciplinar".

${ }^{13}$ DERRIDA, Jacques. A escritura e a diferença. Tradução: Maria Beatriz Marques Nizza da Silva. 2. ed. São Paulo: Perspectiva, 1995.
} 
representação é, portanto, pensar o poder cruel da morte e do jogo que permite a presença de nascer para si, de usufruir de si pela representação em que ela se furta na sua diferença. O teatro de Suassuna é a representação não representável da vida de seus personagens; é a possibilidade artística que permite essa interlocução jurídica porque a criação não inventa, mas descobre o que é dado no objeto construído.

Antes do episódio chave da peça - o julgamento - volta-se a algumas considerações das duas cenas anteriores para que se possa compreender os fatos que dão ensejo a este. $\mathrm{O}$ autornão se coloca acima do diálogo numa posição superior, pelo contrário, apresenta-se como o palhaço da peça, ele garante para si o expediente puramente e necessário à condução da narração, com base na teoria do romance polifônico, em que todos os personagens têm voz, em que há observância à alteridade, e o discurso é marcado por uma dialogicidade ${ }^{14}$ interna, condicionada pela singularidade e insubstitubilidade de cada personagen no seu lugar no mundo, desenvolvida por Bakhtin $^{15}$.

Em Auto da Compadecida, os três atos que marcam os episódios principais da peça literária são entrecortados pelas falas do palhaço, que representa o autor ${ }^{16}$ e pelo toque de clarim. Os personagens são João Grilo, Chicó, Padre João, Antonio Morais, Sacristão, Padeiro, Mulher do Padeiro, Bispo, Frade, Cangaceiro Severino do Aracaju, todos se aproximam dos tipos reais dos homens do sertão nordestino. Até mesmo o Encourado (O Diabo), A Compadecida (Nossa Senhora) - "sua mãe é gente como eu, só que gente muito boa, enquanto que eu nao valho nada" - nas palavras de João Grilo ${ }^{17}$, e Manuel (Nosso Senhor Jesus Cristo), que na peça diz “e eu não sou gente, João? Sou homem, judeu, nascido em Belém, criado em Nazaré, fui ajudante de carpinteiro... Tudo

\footnotetext{
${ }^{14}$ BAKHTIN, Mikhail. O autor e a personagem na atividade estética. In: Estética da criação verbal. 4. Ed.Tradução: Paulo Bezerra. São Paulo: Martins Fontes, 2006. p. 21. "Porque em qualquer situação ou proximidade que esse outro que contemplo possa estar em relação a mim, sempre verei e saberei algo que ele, da sua posição fora e diante de mim, não pode ver: as partes de seu corpo inacessíveis ao seu próprio olhar - a cabeça, o rosto, e sua expressão -, o mundo atrás dele, toda uma série de objetos e relações que, em função dessa ou daquela relação de reciprocidade entre nós, são acessíveis a mim e inacessíveis a ele. [...] Esse excedente da minha visão [...] é condicionado pela singularidade e pela insubstitubilidade do meu lugar no mundo".

${ }^{15}$ BAKHTIN, Mikhail. Problemas da poética de Dostoiévski. 4a . Ed. Rev. e Ampl. Tradução: Paulo Bezerra. Rio de Janeiro: Forense Universitária, 2008. p. 73-83. "De algum modo, mesmo na literatura não existe um estatuto absoluto da invenção. Toda criação é concatenada tanto por suas leis próprias quanto pelas leis do material sobre o qual ela trabalha. Toda criação é determinada por seu objeto e sua estrutura e por isto não admite o arbítrio e, em essência, nada inventa, mas apenas descobre aquilo que é dado no próprio objeto".

${ }^{16}$ SUASSUNA, Ariano. Auto da Compadecida. 11 ${ }^{\mathrm{a}}$. Ed. Rio de Janeiro: Livraria AGIR, 1975. p. 23. "Mais do que ninguém sabe que sua alma é um velho catre, cheio de insensatez e de solércia".

${ }^{17}$ SUASSUNA, Ariano. Auto da Compadecida. 11ª. Ed. Rio de Janeiro: Livraria AGIR, 1975. p. 174.
} 
isso vale alguma coisa"18, apesar de se encontrarem num lugar de maior prestígio, por fazerem aacusação, a defesa e o julgamento, não têm características de divindade, ou de seres superiores.

Suassuna pede que a peça seja encenada ${ }^{19}$ seguindo a maior linha de simplicidade e que o cenário seja um picadeiro de circo e apresente uma entradade igreja à direita, com uma pequena balaustrada ao fundo, uma vez que o centro do palco representa um desses pátios comuns nas igrejas e vilas do interior. "Trata-se de uma história altamente moral e um apelo à misericórdia", anuncia o Palhaço, completado por João Grilo: "Ele diz „à misericórdiae, porque sabe que, se fôssemos julgados pela justiça, toda a nação seria condenada". ${ }^{20}$

João Grilo é descrito como "um amarelo muito safado", que não tem medo de nada, que "é louco por uma embrulhada, porque só assim pode se divertir"21, e ao lado de Chicó, seu fiel amigo, protagonizam cenas que vão do cômico ao trágico, e ao jurídico, em busca de dinheiro e comida. Alegorias, inventividade e capacidade para recriar o mundo, são características dos dois personagens. O primeiro plano dos dois é conseguir que o Padre benza o cachorro da mulher do padeiro. O Padre se nega, e Chicó questiona por qual motivo ele benzeu um motor. Ao que o Padre responde: "Benzer motor é fácil, todo mundo faz isso, mas benzer cachorro? ${ }^{22 "}$. As cenas se desenvolvem no sentido de mostrar que os tipos humanos são passíveis de erros: a mulher do padeiro engana o marido ${ }^{23}$; João Grilo é vingativo - "deixe de ser vingativo que você se desgraça, diz Chicó sobre o amigo"24; o Coronel Antonio Morais representa os donos de terra e a velha ordem senhorial quando diz: “os donos da terra é que perderam hoje em dia o senso de autoridade. Veem-se senhores trabalhando em suas terras como qualquer foreiro. Mas comigo as coisas são como antigamente, a velha ociosidade senhorial" ${ }^{25}$. O Padre abusa do poder que lhe foi dado e se mostra subserviente ao Coronel.

Desenvolve-se a história, percebe-se uma clara denúncia da exploração de classes sociais através de uma cosmovisão carnavalesca e do riso, tornando a peça conscientizadora pelo humor, pelo cômico, "quem gosta de tristeza é o diabo", diz A

\footnotetext{
${ }^{18}$ SUASSUNA, Ariano. Auto da Compadecida. 11 ${ }^{\mathrm{a}}$. Ed. Rio de Janeiro: Livraria AGIR, 1975. p. 165.

${ }^{19}$ SUASSUNA, Ariano. Auto da Compadecida. 11 a . Ed. Rio de Janeiro: Livraria AGIR, 1975.p. 21.

${ }^{20}$ SUASSUNA, Ariano. Auto da Compadecida. 11 ${ }^{\mathrm{a}}$. Ed. Rio de Janeiro: Livraria AGIR, 1975.p. 24.

${ }^{21}$ SUASSUNA, Ariano. Auto da Compadecida. 11 a . Ed. Rio de Janeiro: Livraria AGIR, 1975.p. 39.

${ }^{22}$ SUASSUNA, Ariano. Auto da Compadecida. 11 a . Ed.. Rio de Janeiro: Livraria AGIR, 1975.p. 33.

${ }^{23}$ SUASSUNA, Ariano. Auto da Compadecida. 11 a . Ed.. Rio de Janeiro: Livraria AGIR, 1975.p. 37.

${ }^{24}$ SUASSUNA, Ariano. Auto da Compadecida. 11 a . Ed. Rio de Janeiro: Livraria AGIR, 1975.p. 39.

${ }^{25}$ SUASSUNA, Ariano. Auto da Compadecida. 11 a . Ed. Rio de Janeiro: Livraria AGIR, 1975.p. 44.
} 
Compadecida $^{26}$. O Padre afirma que, na profissão dele, "a gente se acostuma de tal modo com isso de dar e tomar... O próprio direito à graça só se consegue cumprindo os mandamentos"27. Chicó enuncia um preceito filosófico, ouvido de um padre, quando descobre que o cachorro da mulher do padeiro morreu, que disse ter ouvido de um padre, numa clara demonstração de que seus conhecimentos foram aprendidos pela oralidade: "Cumpriu sua sentença e encontrou-se com o único mal irremediável, aquilo que é a marca de nosso estranho destino sobre a terra, aquele fato sem explicação que iguala tudo o que é vivo num só rebanho de condenados, porque tudo o que é vivo morre",28.

João Grilo convence o Padre a sepultar o cachorro em latim, quando anuncia para este que o cachorro tinha um testamento e que, em troca do enterro, deixou 10 contos para o padre e três para o sacristão. "Que cachorro inteligente! Que sentimento nobre!"29. Ao que João Grilo diz "um cachorro desse ser comido pelos urubus! É a maior das injustiças ${ }^{30}$ ". Dentre outras falas, termina o primeiro ato.

No início do segundo ato, ocorre o diálogo do Padre, João Grilo e do Bispo: "um cachorro enterrado em latim? João Grilo: "E então? É proibido? Bispo: se é proibido? Deve ser, porque é engraçado demais para não ser. É proibido! É mais do eu proibido! Código canônico, art. 1627, parágrafo único, letra k. Padre, o senhor vai ser suspenso"31. O Bispo, quando ficou sabendo que quatro contos de reis foram para a paróquia e seis para a diocese, mudou de opinião sobre o enterro do cachorro: "Não resta nenhuma dúvida, foi tudo legal, certo e permitido. Código Canônico, artigo 368, parágrafo terceiro, letra $\mathrm{b}^{\text {"32 }}$.

Na continuidade dos atos mundanos, o Padeiro e João Grilo se insultam por "ladrão 33 ", em seguida, João Grilo manda "vão-se danar todos, sacristão, padeiro, padre, bispo, porque eu já estou cheio"34. Na cena seguinte, aparece Severino de Aracaju, o Cangaceiro, que diz "que não tem ninguém por ele e que pode ser assassino, mas não

\footnotetext{
${ }^{26}$ SUASSUNA, Ariano. Auto da Compadecida. $11^{\mathrm{a}}$. Ed. Rio de Janeiro: Livraria AGIR, 1975.p. 171.

${ }^{27}$ SUASSUNA, Ariano. Auto da Compadecida. $11^{\mathrm{a}}$. Ed. Rio de Janeiro: Livraria AGIR, 1975.p. 48-49.

${ }^{28}$ SUASSUNA, Ariano. Auto da Compadecida. 11 ${ }^{\mathrm{a}}$. Ed. Rio de Janeiro: Livraria AGIR, 1975.p. 56.

${ }^{29}$ SUASSUNA, Ariano. Auto da Compadecida. 11 a . Ed. Rio de Janeiro: Livraria AGIR, 1975.p. 64.

${ }^{30}$ SUASSUNA, Ariano. Auto da Compadecida. 11 a . Ed. Rio de Janeiro: Livraria AGIR, 1975.p. 68.

${ }^{31}$ SUASSUNA, Ariano. Auto da Compadecida. 11 a . Ed. Rio de Janeiro: Livraria AGIR, 1975.p. 83.

${ }^{32}$ SUASSUNA, Ariano. Auto da Compadecida. 11 a . Ed. Rio de Janeiro: Livraria AGIR, 1975.p. 100.

${ }^{33}$ SUASSUNA, Ariano. Auto da Compadecida. 11 ${ }^{\mathrm{a}}$. Ed. Rio de Janeiro: Livraria AGIR, 1975.p. 103.

${ }^{34}$ SUASSUNA, Ariano. Auto da Compadecida. 11 ${ }^{\mathrm{a}}$. Ed. Rio de Janeiro: Livraria AGIR, 1975.p. 105.
} 
mata ninguém sem motivo ${ }^{35}$ ". Severino de Aracaju mata na sequência o Bispo, o Padre, o Sacristão, o Padeiro e a Mulher do Padeiro que morrem juntos de um tiro só. Neste instante do espetáculo, ficam em cena somente Severino de Aracaju e outro cangaceiro, João Grilo e Chicó. É quando João Grilo rapidamente percebe que podia enganar o Cangaceiro: dá uma punhalada numa bexiga cheia de sangue que Chicó trazia na barriga, Chicó cai ao chão, apalpa-se e entende o plano do amigo. João Grilo diz para Severino: está vendo o sangue? Severino, responde: "Estou. Vi você dar a facada, disso nunca duvidei. Agora, quero ver é você curar o homem ${ }^{36,}$. João Grilo começa tocar a gaita, e Chicó começa a se mover no ritmo da música, e diz que viu Nossa Senhora e Padre Cícero no céu e que este mandou a gaita para Severino de Aracaju. Severino acredita, pede que o outro cangaceiro atire nele. João Grilo enfia a faca na barriga do outro cangaceiro que cai, mas ainda tem forças para se reerguer e matar João Grilo com um tiro de um rifle, tendo sobrado na cena somente Chicó.

Do desfecho dos personagens sendo assassinados, para o Palhaço, "uma carnifica"37, passasse-se à cena do julgamento do Auto da Compadecida, "com toda essa gente morta, o espetáculo continua e terão oportunidade de assistir seu julgamento. Espero que todos os presentes aproveitem os ensinamentos desta peça e reformem suas vidas, se bem que eu tenha certeza de que todos os que estão aqui são uns verdadeiros santos, praticantes da virtude, do amor a Deus e ao próximo, sem maldade, sem mesquinhez, incapaz de julgar e de falar mal dos outros, generosos, sem avareza, ótimos patrões, excelentes empregados, sóbrios, castos e pacientes" ${ }^{\text {’3 }}$. Em seguida, o Demônio apresenta-se na cena do Julgamento ${ }^{39}$ como o Acusador, o Vingador dos crimes. Manda que todos se calem e silenciem e diz que chegou a hora da verdade e que todos vão pagar por tudo que fizeram. No entanto, além do Demônio, aparece como outro Acusador o Encourado ${ }^{40}$, "este é o diabo, que, segundo uma crença do sertão do Nordeste, é um homem muito moreno, que se veste como um vaqueiro”. O Encourado diz: "Que vergonha! Todos tremendo! Tão corajosos antes, tão covardes agora! O Senhor Bispo, tão cheio de dignidade, o padre, o valente Severino... E você, Grilo que

\footnotetext{
${ }^{35}$ SUASSUNA, Ariano. Auto da Compadecida. 11 ${ }^{\mathrm{a}}$. Ed. Rio de Janeiro: Livraria AGIR, 1975.p. 112-113.

${ }^{36}$ SUASSUNA, Ariano. Auto da Compadecida. 11 ${ }^{\mathrm{a}}$. Ed. Rio de Janeiro: Livraria AGIR, 1975.p. 124.

${ }^{37}$ SUASSUNA, Ariano. Auto da Compadecida. 11 ${ }^{\mathrm{a}}$. Ed. Rio de Janeiro: Livraria AGIR, 1975.p. 134.

${ }^{38}$ SUASSUNA, Ariano. Auto da Compadecida. 11'. Ed. Rio de Janeiro: Livraria AGIR, 1975.p. 137.

${ }^{39}$ SUASSUNA, Ariano. Auto da Compadecida. 11 a . Ed. Rio de Janeiro: Livraria AGIR, 1975.p. 139.

${ }^{40}$ SUASSUNA, Ariano. Auto da Compadecida. 11 ${ }^{\mathrm{a}}$. Ed. Rio de Janeiro: Livraria AGIR, 1975.p. 140.
} 
enganava todo o mundo, tremendo como qualquer safado"41. O Encourado convoca todos para padecerem no fogo eterno do inferno. Neste momento, João Grilo, aparece como o primeiro defensor ${ }^{42}$ : “É assim de vez? É só dizer „pra dentro"e vai tudo? Que diabo de tribunal é esse que não tem apelação?”.

O Encourado diz que não tem apelação e João Grilo retruca e afirma que para se condenar uma pessoa ela tem de ser ouvida ${ }^{43}$. Neste momento, todos os outros acusados concordam com João Grilo. O Padre ${ }^{44}$ diz: "sou um padre e tenho meus direitos. Quero ser julgado antes de ser entregue ao diabo”. Entra Manuel ${ }^{45}$ que anuncia: "levantem-se todos, pois vão ser julgados" e diz que o Encourado gosta de chamá-lo por Manuel ou Emanuel na tentativa de persuadi-lo de que é somente homem. O Encourado, para João Grilo, “é uma mistura de promotor, sacristão, cachorro e soldado de polícia gente que ele nunca suportou" 46 . Manuel, enquanto juiz que decidirá pela absolvição ou condenação dos acusados, pede que o Encourado comece a fazer a acusação.

O Encourado diz que os crimes cometidos pelo Bispo também se aplicam ao Padre: simonia $^{47}$ (negociou com o cargo, aprovando o enterro de um cachorro em latim, porque o dono lhe deu seis contos), falso testemunho (citou levianamente o Código Canônico, primeiro para condenar o ato do padre e contentar o Coronel Antonio Morais, depois para justificar o enterro); velhacaria (o bispo não passava de um político, apodrecido de sabedoria mundana), arrogância e falta de humildade no desempenho de suas funções e soberba. O Padre, além destes, também tem: falta de coleguismo e preguiça de acordo com O Encourado. João Grilo tenta se meter e ajudar na acusação do sacristão, quando Manuel o repreende e diz que deixe a acusação com o Encourado. Em meio a protesto do Encourado, Manuel pede que este faça a acusação do sacristão. $\mathrm{O}$ Encourado acusa de ter sido o sacristão quem tramou a história do enterro do cachorro, o acusa também de hipocrisia, autossuficiência e roubo contra a igreja.

Manuel diz "faz tempo que não vejo tanta coisa ruim junta" ${ }^{48 "}$. O Encourado continua sua acusação. Desta vez contra o Padeiro e sua Mulher. Diz que os dois foram os piores patrões que Taperoá já viu; avareza do marido e adultério da mulher. Contra

\footnotetext{
${ }^{41}$ SUASSUNA, Ariano. Auto da Compadecida. 11 ${ }^{\mathrm{a}}$. Ed. Rio de Janeiro: Livraria AGIR, 1975.p. 141.

${ }^{42}$ SUASSUNA, Ariano. Auto da Compadecida. 11 ${ }^{\mathrm{a}}$. Ed. Rio de Janeiro: Livraria AGIR, 1975.p. 143.

${ }^{43}$ SUASSUNA, Ariano. Auto da Compadecida. 11 ${ }^{\mathrm{a}}$. Ed. Rio de Janeiro: Livraria AGIR, 1975.p. 144.

${ }^{44}$ SUASSUNA, Ariano. Auto da Compadecida. $11^{\mathrm{a}}$. Ed. Rio de Janeiro: Livraria AGIR, 1975.p. 145.

${ }^{45}$ SUASSUNA, Ariano. Auto da Compadecida. 11 ${ }^{\mathrm{a}}$. Ed. Rio de Janeiro: Livraria AGIR, 1975.p. 146.

${ }^{46}$ SUASSUNA, Ariano. Auto da Compadecida. $11^{\mathrm{a}}$. Ed. Rio de Janeiro: Livraria AGIR, 1975.p. 150.

${ }^{47}$ SUASSUNA, Ariano. Auto da Compadecida. 11 ${ }^{\mathrm{a}}$. Ed.. Rio de Janeiro: Livraria AGIR, 1975.p. 150.

${ }^{48}$ SUASSUNA, Ariano. Auto da Compadecida. 11 a . Ed. Rio de Janeiro: Livraria AGIR, 1975.p. 156.
} 
Severino e o outro cangaceiro, o Encourado diz que ambos mataram mais de trinta. $\mathrm{O}$ Encourado pede: "inferno nele ${ }^{49}$ ". É Manuel quem pondera: "Espere, isso também não é assim de repente não! ${ }^{50 "}$. João Grilo gosta da advertência dada por Manuel contra o Encourado e diz "tenho visto poucos sujeitos levar carão e ficar com cara lisa como esse $^{51 \%}$.

O Encourado tem certeza da vitória da acusação porque a situação está favorável para ele e diz que Manuel é justo e que ele entregará os acusados para oEncourado. Manuel confirma que as acusações são graves à Mulher do Padeiro. $\mathrm{O}$ Bispo grita: Valha-me Deus; o Padre invoca São João, seu padroeiro, e pede para não ir para o inferno. Manuel pergunta qual a defesa de João Grilo. Ao que questiona: desculpe, mas não fui acusado de coisa nenhuma ${ }^{52}$. João Grilo diz que o Encourado não pode mais acusar porque a hora da acusação já passou. Ao que Manuel esclarece: “deixe de chicana, João, você pensa que isso aqui é o palácio da justiça? Pode acusar ${ }^{53}$ ".

O Encourado começa a acusação contra João Grilo: “Agora você me paga, amarelo. O sacristão, o padre e o bispo fizeram o enterro do cachorro, mas a história foi toda tramada por ele. E vendeu um gato à mulher do padeiro dizendo que botava

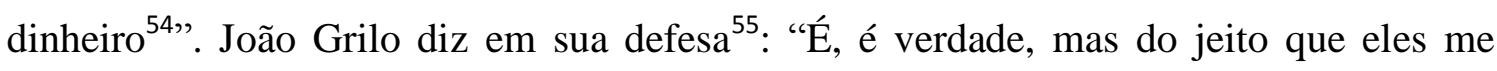
pagavam, o jeito era eu me virar. Além disso, eu estava com pena do gato, tão abandonado, e queria que ele passasse bem". O Encourado continua a acusação: "Foi ele quem matou Severino e o cabra dele". João Grilo se defende e diz que foi por legítima defesa. O Encourado pede apelo para a justiça ${ }^{56}$ e João Grilo, para a misericórdia ${ }^{57}$.

O Padre, desacreditado na defesa, afirma que estudou uma lição que diz que não há contradição entre a justiça e a misericórdia. João Grilo fala que a situação pode ser difícil, mas não é sem jeito. João Grilo diz que os demais acusados tiveram tudo na terra e que "se tivessem tido que aguentar o rojão de João Grilo, passando fome e

\footnotetext{
${ }^{49}$ SUASSUNA, Ariano. Auto da Compadecida. $11^{\mathrm{a}}$. Ed. Rio de Janeiro: Livraria AGIR, 1975.p. 158. ${ }^{50}$ SUASSUNA, Ariano. Auto da Compadecida. 11 ${ }^{\mathrm{a}}$. Ed. Rio de Janeiro: Livraria AGIR, 1975.p. 159. ${ }^{51}$ SUASSUNA, Ariano. Auto da Compadecida. $11^{\mathrm{a}}$. Ed.. Rio de Janeiro: Livraria AGIR, 1975.p. 159. ${ }^{52}$ SUASSUNA, Ariano. Auto da Compadecida. 11 ${ }^{\mathrm{a}}$. Ed.. Rio de Janeiro: Livraria AGIR, 1975.p. 162. ${ }^{53}$ SUASSUNA, Ariano. Auto da Compadecida. 11 ${ }^{\mathrm{a}}$. Ed.. Rio de Janeiro: Livraria AGIR, 1975.p. 162. ${ }^{54}$ SUASSUNA, Ariano. Auto da Compadecida. 11 ${ }^{\mathrm{a}}$. Ed.. Rio de Janeiro: Livraria AGIR, 1975.p. 162. ${ }^{55}$ SUASSUNA, Ariano. Auto da Compadecida. 11 a . Ed. Rio de Janeiro: Livraria AGIR, 1975.p. 163. ${ }^{56}$ SUASSUNA, Ariano. Auto da Compadecida. 11 ${ }^{\mathrm{a}}$. Ed. Rio de Janeiro: Livraria AGIR, 1975.p. 166.

${ }^{57}$ SUASSUNA, Ariano. Auto da Compadecida. 11 ${ }^{\mathrm{a}}$. Ed. Rio de Janeiro: Livraria AGIR, 1975.p. 167.
} 
comendo macambira na seca, garanto que tinham mais coragem ${ }^{58 \%}$. E pergunta se o Padre o quer ver dando um jeito na situação? Ao que todos os demais acusados respondem que querem e que João Grilo é a esperança deles. João Grilo invoca a mãe da justiça (a mãe de Manuel), a misericórdia. O Encourado, com raiva, afirma: "Lá vem a compadecida! Mulher em tudo se mete! $!^{59}$ ". Portanto, a defesa ganhou uma aliada: A Compadecida. O Encourado diz que a Compadecida termina desmoralizando tudo, com tanto chamego que ela faz para salvar todo mundo.

A Compadecida intercede por todos os acusados e pede que Manuel não os condene $^{60}$, e diz "é verdade que eles praticaram atos vergonhosos, mas é preciso levar em conta a pobre e triste condição do homem”. Alega ainda em favor da Mulher do Padeiro "a condição de mulher escravizada pelo marido e sem grande possibilidade de se libertar. Que posso alegar ainda em seu favor? ${ }^{61 "}$. Depois, a Compadecida alega que Severino de Aracaju e o outro cangaceiro enlouqueceram depois que a polícia matou a família deles e que ambos não são responsáveis por seus atos. Manuel acata a alegação ao que Severino e o cangaceiro saem para o céu.

O Encourado pede que seja dada a sentença dos demais. Manuel diz que vai proferi-la, mas, antes disso, João Grilo intercede e pede que os acusados sejam encaminhados para o purgatório, e não para o inferno. A Compadecida compactua com a ideia apresentada por João Grilo e diz: “É uma boa solução, meu filho. Dá para eles pagarem o muito que fizeram e assegura a sua salvação ${ }^{62 " . ~ M a n u e l ~ c o n c e d e ~ e s s a ~}$ penalidade, e os cinco acusados, o Padre, o Bispo, o Sacristão, o Padeiro e a Mulher do Padeiro vão para o Purgatório. João Grilo diz que o caso dele é de salvação direta. A Compadecida intervém e pede que ele volte à vida terrena. Manuel aceita com uma condição: que João Grilo lhe faça uma pergunta que ele não possa responder. João Grilo pergunta quando será a volta de Manuel ao mundo? Manuel diz que é um grande mistério e não responde. João Grilo ganha o desafio, agradece à Compadecida, "grande advogada ${ }^{63}$ ". Manuel diz à Compadecida: "se a senhora continuar a interceder desse jeito por todos, o inferno vai terminar como disse Murilo: feito repartição pública, que

\footnotetext{
${ }^{58}$ SUASSUNA, Ariano. Auto da Compadecida. 11 ${ }^{\text {a }}$. Ed. Rio de Janeiro: Livraria AGIR, 1975.p. 167. ${ }^{59}$ SUASSUNA, Ariano. Auto da Compadecida. 11 ${ }^{\mathrm{a}}$. Ed. Rio de Janeiro: Livraria AGIR, 1975.p. 170. ${ }^{60}$ SUASSUNA, Ariano. Auto da Compadecida. 11 ${ }^{\mathrm{a}}$. Ed.. Rio de Janeiro: Livraria AGIR, 1975.p. 174. ${ }^{61}$ SUASSUNA, Ariano. Auto da Compadecida. $11^{\mathrm{a}}$. Ed. Rio de Janeiro: Livraria AGIR, 1975.p. 179. ${ }^{62}$ SUASSUNA, Ariano. Auto da Compadecida. 11 ${ }^{\mathrm{a}}$. Ed. Rio de Janeiro: Livraria AGIR, 1975.p. 182.

${ }^{63}$ SUASSUNA, Ariano. Auto da Compadecida. 11 a . Ed. Rio de Janeiro: Livraria AGIR, 1975.p. 189.
} 
existe, mas não funciona ${ }^{64 "}$. Chicó havia feito uma promessa à Nossa Senhora para dar todo o dinheiro do testamento do cachorro se João Grilo escapasse. João Grilo diz, por fim, que o dinheiro fica sendo os honorários da advogada - "nunca pensei que essa também aceitasse pagamento ${ }^{65}$ ". O Auto da Compadecida termina.

\section{CONCLUSÕES:}

Histórias de vida em um julgamento, histórias de vida representadas em cenas memoráveis da literatura brasileira, é assim que se concebe Auto da Compadecida. A obra de Suassuna é aberta, plural, por este motivo não se quis enveredar pelo julgamento dos personagens na narrativa do autor, optou-se por uma apresentação compactada e o mais fiel possível da forma como Suassuna apresentou o Julgamento no Auto da Compadecida. Nesta linha de intersecção dialógica entre Direito e Arte, entre Direito e Literatura, entre Direito e Teatro, percebe-se que as construções imagéticodiscursivas sobre o Tribunal num Júri se assemelham muito à própria concepção cristã da formação de um Tribunal. De acordo com Batista ${ }^{66}$ o Direito Canônico se erigiu como a vontade de Deus revelada aos homens de boa esperança cuja obediência se mostrava como um dever, uma imposição ética justificada pela origem divina. Os traços da tradição católica são perceptíveis na obra, a exemplodo julgamento ser feito pela Justiça, representado por Deus.

A cosmovisão de cada personagem é representativa das multiplicidades das atuações dos seres humanos em seus palcos artísticos e representa para o Direito a possibilidade da invenção de leis e castigos para o disciplinamento dos homens. A utilização de processos judiciais penais pode ser compreendida por meio da noção de romance polifônico defendida por Bakhtin ${ }^{67}$ quando expõe que arte e vida se entrelaçam

\footnotetext{
${ }^{64}$ SUASSUNA, Ariano. Auto da Compadecida. 11 ${ }^{\mathrm{a}}$. Ed. Rio de Janeiro: Livraria AGIR, 1975.p. 190. ${ }^{65}$ SUASSUNA, Ariano. Auto da Compadecida. 11'. Ed. Rio de Janeiro: Livraria AGIR, 1975.p. 202.

${ }^{66}$ BATISTA, Nilo. Matrizes ibéricas do sistema penal brasileiro. Rio de Janeiro: Revan, 2002. p. 163270. HAUSER, Ester Eliana; MARTEL, Letícia. Tribunais, Magistrados e Feiticeiras na Europa Moderna. In: SANTOS, Rogério Dultra dos (Org.). Introdução crítica ao estudo do sistema penal. Florianópolis: Diploma Legal, 1999.p. 205-256. Auto-legitimando-se como a portadora da palavra divina e mantendo sob crença os fiéis, pela submissão do amor prometido ou mesmo pela força - Inquisição -, a Igreja protraiu sua legitimação, manifestada por suas normas e seu processo. O Direito Canônico se erige, então, como a vontade de Deus revelada aos homens de boa esperança (de um mundo melhor), cuja obediência se mostrava como um dever, uma imposição ética justificada pela origem divina.

${ }^{67}$ BAKHTIN, Mikhail. A Cultura Popular na Idade Média e no Renascimento: o contexto de François Rabelais. Tradução: Yara Frateschi Vieira. São Paulo: Hucitec; Brasília: Editora Universidade de Brasília,
} 
e que se situa nas fronteiras entre a arte e a vida. $\mathrm{Na}$ realidade, é a própria vida apresentada com os elementos característicos da representação que foi. $\mathrm{Na}$ obra de Suassuna, percebe-se a abertura e a pluralidade de interlocuções, pois todos os personagens expõem suas ideologias, sem que nenhum deles prevaleça sobre os demais. Isso é representativo de um discurso polifônico que, nas palavras de Schnaiderman ${ }^{68}$, significam que não há uma voz bem definida que articule tudo, de acordo com a ideologia do autor, mas uma multiplicidade de vozes entre atores e espectadores num espetáculo encenado.

Auto da Compadecidade é um drama cômico em três atos, cujo palco resume o grande teatro do mundo, microcosmo que simboliza a história da humanidade. É representativo de uma transcedência, que se funde na própria teatralidade dos homens enquanto criadores e criaturas de um espetáculo existencial, em que as leis se mesclam às suas existências no sentido de permitir ou nao permitir comportamentos. Para Bauman $^{69}$ a afirmação de que a vida imita a arte nao é um postulado ou advertência, mas uma declaração de um fato. A vida humana, enquanto obra de arte, é dotada de liberdade e vontade de escolha. Para $\operatorname{Sartre}^{70}$, a emoção é uma transformação do mundo e, neste sentido, pensar Auto da Compadecida numa visão jurídica é perceber que cada personagem, antes de ter uma atuação jurídica, tem uma atuação existencial e, em consequência de suas emoções, provoca alguma transformação no mundo.

Num sentido metafórico e dialógico, os personagens podem ser assim compreendidos: o Promotor é o Encourado e o Assistente de Acusacao é o Diabo; o Advogado é João Grilo e a Advogada de Defesa é a Compadecida, também chamade de “A Misericórdia”; Manuel é o Juiz, o Deus, a Justiça, quem julga e oferece um veredicto; o Padre, o Sacristão, o Padeiro, a Mulher do Padeiro, os Cangaceiros são os acusados. Para os leitores, espectadores, plateia, Obra Aberta constitui-se em útil

2008. p. 4-5. A presença do elemento cômico na vida do Homem Medieval já foi analisado por Bakhtin: "Ofereciam uma visão do mundo, do homem e das relações humanas totalmente diferente, deliberadamente não-oficial, exterior à Igreja e ao Estado; pareciam ter construído, ao lado do mundo oficial, um segundo mundo e uma segunda vida aos quais os homens da Idade Média pertenciam em maior ou menor proporção, e nos quais eles viviam em ocasiões determinadas. Isso criava uma espécie de dualidade do mundo e cremos que, sem levá-la em consideração, não se poderia compreender nem a consciência cultural da Idade Média nem a civilização renascentista".

${ }^{68}$ SCHNAIDERMAN, B. Turbilhão e Semente: Ensaios sobre Dostoiévski e Bakhtin. São Paulo: Duas Cidades, 1983. p. 46. não há uma voz bem definida que articule tudo, de acordo com a ideologia do autor, mas aparece uma multiplicidade de vozes. Cada personagem expõe sua ideologia, sem que uma delas prevaleça sobre as demais.

${ }^{69}$ BAUMAN, Zygmunt. A arte da vida. Tradução: Carlos Alberto Medeiros. Rio de Janeiro: Zahar, 2009.p. 72.

${ }^{70}$ SARTRE, Jean-Paul. Esboço para uma teoria das emoções. Porto Alegre: L\&PM, 2011. p. 63. 
instrumento para análise de Auto da Compadecida ou de um julgamento no Tribunal do Júri Brasileiro, cuja meta principal é a compreensão do papel de cada um dos personagens, seja no mundo da literatura de Suassuna ou no mundo da oratória dos acusadores e defensores. Ler um livro como Auto da Compadecida, assistir sua encenação ou ser jurado num Tribunal do Júri mexe com as emoções humanas.

Apesar de muitas semelhanças a um Tribunal do Júri real, a principal diferença jurídica no Auto da Compadecida é quem julga. Ao invés de vários jurados, a representatividade do julgador dá-se por uma única pessoa, representando a Justica. No entanto, acima da Justiça, como intermediadora dos atos humanos, aparece a Misericórdia, para demonstrar que todos os seres humanos sao passíveis de erros e, numa visão católica que a obra permite, de pecados. Os personagens, portanto, representam a dualidade humana. $\mathrm{O}$ didatismo religioso mostra que os personagens da obra, escolhidos com base no imaginário nordestino, vivem com medo da polícia e do inferno; que, se não houvesse a Justiça, os homens não teriam como conviver em sociedade porque se despedaçariam entre si, pela falta de limites; e que a Justiça, apesar de criticada, acerta seus veredictos.

O ator representa, ensaia, trabalha as emoções a serem transmitidas. As lágrimas de uma tragédia, de um assassinato na vida real são mais tocantes do que as lágrimas causadas por uma narrativa tocante? Para Sennett ${ }^{71}$, "as lágrimas da vida real são imediatas e diretas, enquanto as lágrimas provocadas pela arte precisam ser produzidas conscienciosa, gradativamente". Como mostrar o mundo assim como ele é? Suassuna trouxe para sua obra uma representatividade real de situações concretas, no entanto proporcionou uma reanálise do Júri a partir de uma ótica católica, dando três possibilidades para o julgamento: inferno (condenação), céu (absolvição) e purgatório (um espaço para purgar os pecados antes de chegar ao céu) ${ }^{72}$. Cumpre à culpabilidade, de acordo com Albuquerque Mello ${ }^{73}$, averiguar as situações concretas do caso e se deve

\footnotetext{
${ }^{71}$ SENNETT, Richard. O Declínio do Homem Público: as tiranias da intimidade. Tradução: Lygia Araújo Watanabe. São Paulo: Companhia das Letras, 1998.p. 143.

${ }^{72}$ DUBY, Georges. Idade Média, Idade dos Homens: do amor e outros ensaios. São Paulo: Companhia das Letras. 1989.

${ }^{73}$ ALBUQUERQUE MELLO, Sebastian Borges de. O Conceito material de culpabilidade: O fundamento da imposição da pena a um indivíduo concreto em face da dignidade da pessoa humana. Salvador: JusPodivm, 2010.p.13. O homem deve ser julgado como portador de um valor mínimo intrínseco, igual para todo ser humano, mas também como ser único e irrepetível, com particularidades, valores, circunstâncias e idiossincrasias próprias da condição humana, as quais devem ser levadas em consideração para que seja minimamente legítima a imposição da pena em face das condições e circunstâncias pessoais do autor da infração. Cumpre à culpabilidade analisar as peculiaridades do indivíduo concreto e averiguar se este deverá ou não, em face da ordem jurídica vigente, sofrer a
} 
sofrer a sanção penal de acordo com o que prescreve a lei. Na obra de Suassuna, portanto, a sanção penal maior é ser condenado ao inferno; na realidade jurídica brasileira da condenação no Tribunal do Júri, a sanção é a prisão.

Aplicando-se a teoria do caos à obra Auto da Compadecida e ao Tribunal do Júri questiona-se a possibilidade de fazer-se previsões de longo prazo de qualquer sistema, e neste sentido dentro do Direito, porque a Compadecida e a defesa do no júri analisam o crime como algo relacionado ao passado do acusado. Analisa-se o perfil, as questões familiares e culturais e encadeiam-se essas situações como determinantes para a execução do crime. Se o passado é causa, as pessoas podem usá-lo para justificar os crimes contra a vida no presente, no entanto acredita-se que os crimes não nascem no passado e que, ao contrário, é decisão do presente, obedecendo ao livre-arbítrio do executante. A Compadecida utiliza-se de uma explicação misericordiosa para justificar comportamentos dos personagens da obra literária; os defensores em tribuna assim também o fazem. A teoria do caos vai de encontro com essa interpretação, pois não há como fazer-se previsões de longo prazo no sistema social e jurídico. Sendo assim, na interpretação dos crimes de Tribunal do Júri analisar o homicida dentro de uma lógica de causa e consequência vai na contramão da incerteza e do caos.

A proposta de Eco de convidar a participação do público nas obras artísticas, tanto é percebida na obra literária e teatral de Suassuna, quando o leitor-espectador dela participa, quanto também numa composição de um julgamento no Brasil em Tribunal do Júri, pois os sete jurados complementam o resultado da obra. De acordo com Lins e Silva $^{74}$, "o Tribunal do Júri é um mundo mágico, forte, flutuante, fluído „kafkaniano ee, é também a luta da razão contra a fé, a luta da razão contra a emoção.

Tomando-se o método apolíneo-dionisíaco proposto por Nietzsche, tem-se que o apolíneo é a beleza do espetáculo das cenas irrepetíveis, da própria criação artística das cenas do cotidiano e das obras artísticas, ao passo que o dionisíaco é a transgressão

ignomínia que a sanção penal representa, pois nem o conceito de injusto nem as finalidades preventivas logram êxito em determinar os fundamentos da imputação pessoal da pena.

${ }^{74}$ LINS E SILVA, Evandro. Discursos. In: SHECAIRA, Sérgio Salomão (Org.). Estudos criminais em homenagem a Evandro Lins e Silva. São Paulo: Método, 2001.p. 14: "O ritual, a solenidade, as becas e togas, até mesmo cabeleiras empoladas, a tribuna, os jurados, o réu, a defesa e a acusação, a assistência, um crime, uma decisão. Não há dados, mas há sorteio. De um lado o lúdico, a álea. Do outro, o suspense, o suor, o talento, a dedicação, a arte, a pertinácia, a ciência, a estética cumprem o papel. A lógica e a adrenalina, o inesperado, o fatídico e o invisível. Cenas que se sucedem neste fantástico espetáculo onde não falta „frisson" e se tem direito a,,gran finale’. Este é o mundo mágico do júri - forte, flutuante, fluído „kafkaniano"." 
do ser humano. Sai-se, portanto, do discurso bíblico e envereda-se numa construção na qual se observa que a justiça que castiga ${ }^{75}$ não é filha da misericórdia, em que se observa que infelicidade e culpa foram postas pelo cristianismo na mesma balança, de modo que, quando é grande a infelicidade que se segue a uma culpa, a grandeza da própria culpa é medida por ela. Para Nietzsche ${ }^{76}$, somos divinos porque detemos a razão e "a razão é a causa de falsearmos o testemunho dos sentidos. Estes não mentem quando nos mostram o vir a ser das coisas, o desaparecimento, a mudança. Mas em sua afirmação segundo a qual o ser é uma ficção, Heráclito terá eternamente razão. $\mathrm{O}$ mundo das aparências é o único real, o mundo, verdade foi acrescentado pela mentira". Percebe-se a indagação ontológica que todo ser humano pode fazer a si mesmo uma abertura para o absurdo do existir. Para Camus"7, “o homem absurdo só pode admitir uma moral, aquela que nao se separa de Deus: a que se dita. Mas ele vive justamente à margem desse Deus". Para Maiakovski ${ }^{78}$, "a arte não é um espelho para refletir o mundo, mas um martelo para forjá-lo”. No Tribunal do Júri, a emotividade apresenta-se na racionalidade da sociedade do espetáculo; no Tribunal do Júri, a razão é absurda, não reflete o mundo, mas é um martelo que o forja; no Tribunal do Júri, o Júri mata Deus.

\section{REFERENCIAIS:}

ALBUQUERQUE JR., Durval Muniz. A invenção do Nordeste e outras artes. 5. ed. São Paulo: Cortez, 2011.

ALBUQUERQUE MELLO, Sebastian Borges de. O Conceito material de culpabilidade: $\mathrm{O}$ fundamento da imposição da pena a um indivíduo concreto em face da dignidade da pessoa humana. Salvador: Jus Podivm, 2010.

BAKHTIN, Mikhail. A Cultura Popular na Idade Média e no Renascimento: o contexto de François Rabelais. Tradução: Yara Frateschi Vieira. São Paulo: Hucitec; Brasília: Editora da Universidade de Brasília, 2008.

O autor e a personagem na atividade estética. In: Estética da criação $\overline{\text { verbal. }}$ 4. ed. Tradução: Paulo Bezerra. São Paulo: Martins Fontes, 2006.

\footnotetext{
${ }^{75}$ NIETZSCHE, Friedrich W. Obras Incompletas. Seleção de textos: Gerard Lebrun. Tradução e notas: Rubens Rodrigues Torres Filho. Posfácio: Antonio Cândido. 3. ed. São: Abril Cultural, 1983.p. 116.

${ }^{76}$ NIETZSCHE, Friedrich. O crepúsculo dos ídolos ou a Filosofia a golpes de martelo. Tradução: Edson Bini e Marcio Pugliesi. Curitiba: Hemus, 2001. p. 22-25.

${ }^{77}$ CAMUS, Albert. O mito de Sísifo. Tradução: Ari Roitman e PulinaWatch. 2. ed. Rio de Janeiro: Best Bolso, 2012.p. 73.

${ }^{78}$ MAIAKOVSKI. Vida e Poesia. Tradução: Emilio C. Guerra e Daniel Fresnot. São Paulo: Martin Claret, 2006. p. 106.
} 
. Problemas da poética de Dostoiévski. 4. ed. rev. e ampl. Tradução: Paulo

Bezerra. Riode Janeiro: Forense Universitária, 2008.

BAUMAN, Zygmunt. A arte da vida. Tradução: Carlos Alberto Medeiros. Rio de Janeiro:Zahar, 2009.

BORDIEU, Pierre. O Poder Simbólico. $3^{\mathrm{a}}$. ed. Tradução: Fernando Tomaz. Rio de Janeiro: Bertrand Brasil, 2000.

BUENO DE CARVALHO, Amilton. O juiz e a jurisprudência: um desabafo crítico. In:BONATO, Gilson (Org.). Garantias Constitucionais e Processo Penal. Rio de Janeiro: Lumen Juris, 2002.p. 4.

. Direito Penal a Marteladas (Algo sobre Nietzsche e o Direito). Rio de Janeiro: Lumen Juris, 2013.

CAMUS, Albert. O avesso e o direito. São Paulo: Record. 1995.

.O mito de Sísifo.2.ed.Tradução: Ari Roitman e PulinaWatch. Rio de Janeiro: BestBolso, 2012.

CERQUEIRA, Nelson. A crítica marxista de Franz Kafka. Tradução:Yvenio Azevedo. Bahia: Cara, 2005.

Hermenêutica e Literatura. Tradução:Yvenio Azevedo. Bahia: Cara, 2003.

CERTEAU, Michel. A invenção do cotidiano: 1. Artes de fazer. Tradução:Ephraim Ferreira Alves. Petrópolis: Vozes, 1994.

CHAUÍ, Marilena. Janelas da Alma, Espelhos do Mundo. In: NOVAES, Adauto (Org.). O olhar. São Paulo: Cia das Letras, 1998. p. 31-63.

CHUEIRI, Vera Karam. Kafka, Shakespeare e Graciliano: tramando o Direito. Revista da Faculdade Mineira de Direito,Belo Horizonte, v. 10, n. 19, p. 119-133,jan./jun. 2007.

COUTINHO, Jacinto Nelson de Miranda. O Papel do Novo Juiz no Processo Penal. In: . (Coord.). Crítica à Teoria Geral do Processo Penal. Rio de Janeiro:

Renovar,2001. p. 3-56.

CUNHA MARTINS, Rui. O Ponto Cego do Direito. The BrazilianLessons. Rio de Janeiro:Lumen Juris, 2010.

DALÍ, Salvador. Libelo Contra a Arte Moderna. Porto Alegre : L\&PM, 2008.

DAMASIO, Antonio R. O Erro de Descartes: Emoção, Razão e o Cérebro Humano. São Paulo: Companhia das Letras, 1996.

DEBORD, Guy. A Sociedade do Espetáculo. Disponível em:<www.geocities.com/ projetoperiferia>. Acesso em:20 maio 2014. 
DELEUZE, Gilles. Controle e Devir.In:

PálPelbart. São Paulo: 34, 1997. p. 209-226.

. Conversações. Tradução: Peter

.Lógica do Sentido. Tradução: Luiz Roberto Salinas Fortes. São Paulo:

Perspectiva, 1974.

DERRIDA, Jacques. A escritura e a diferença. 2.ed.Tradução: Maria Beatriz Marques Nizza da Silva. São Paulo: Perspectiva, 1995.

.Paixões. Tradução:Loriz Z. Machado. São Paulo: Papirus, 1995.

DUBY, Georges. Idade Média, Idade dos Homens: do amor e outros ensaios. São Paulo: Companhia das Letras. 1989.

ECO, Umberto. Obra Aberta: forma e indeterminação nas poéticas contemporâneas. Tradução: Giovanni Cutolo. São Paulo: Perspectiva, 2012.

FERREIRA DA CUNHA, Paulo. Direitos Fundamentais - Fundamentos e direitos sociais. Coimbra: Quid Juris, 2014. (Coleção Erasmus, Ensaios e Monografias - Linha de Direito e Ciências Políticas).

: Forense, 1998.

FITZGERALD, F. S. A Fissura.Gallimard, 1963.

FOUCAULT, Michel. A Ordem do Discurso.7. ed.São Paulo: Loyola, 2001.

. As Palavras e as Coisas: uma arqueologia das ciências humanas. Tradução:

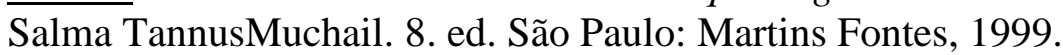

FRANCA FILHO, Marcilio Toscano. A Cegueira da Justiça-Diálogo Iconográfico entre Arte e Direito.Porto Alegre: Sérgio Antonio Fabris, 2003.

FREITAS, Nanci de. A comedia della arte:máscaras, duplicidade e o riso diabólico de Arlequim. Textos escolhidos de cultura e arte populares, Rio de Janeiro, v. 5, n. 1, p. 65-74, 2008. p. 66. Disponível em:

<http://www.tecap.uerj.br/pdf/v5/nanci_de_freitas.pdf>. Acesso em: 18 ago. 2014.

GINZBURG, Carlo. O inquisidor como antropólogo. Tradução: Jônatas Batista

Neto.Revista Brasileira de História, São Paulo, v. 11, n. 21, set. 1990/fev. 1991.

O queijo e os vermes: o cotidiano e as ideias de um moleiro perseguido pela

Inquisição. Tradução: Maria Betânia Amoroso e José Paulo Paes. São Paulo:

Companhia das Letras, 2008.

.Os andarilhos do bem: feitiçaria e cultos agrários nos séculos XVI e XVII. 2.ed. São Paulo: Companhia das Letras, 2008.

GLEICK, James. Caos - a criação de uma nova ciência. Rio de Janeiro: Campus, 1990. 
GOLDBERG, Jacob Pinheiro. O Direito no Divã - Ética da Emoção. São Paulo: Saraiva, 2011.

GOMPERTZ, Will. Isso é arte? 150 anos de arte moderna do impressionismo até hoje. Rio de Janeiro: Zahar, 2013.

HAUSER, Ester Eliana; MARTEL, Letícia. Tribunais, Magistrados e Feiticeiras na Europa Moderna. In: SANTOS, Rogério Dultra dos (Org.). Introdução crítica ao estudo do sistema penal. Florianópolis: Diploma Legal, 1999. p. 205-256.

HEIDEGGER, Martin. Fundamentos metafísicos da lógica. Tradução: Rodolfo Schaefer. São Paulo:Martin Claret, 2003.

JANH, Livia Petry. As raízes ibéricas e populares do teatro de Ariano Suassuna. 2008. 32 f. Monografia (Graduação em Letras) - Universidade Federal do Rio Grande do Sul, Porto Alegre, 2008. Disponível em:

<http://www.lume.ufrgs.br/bitstream/handle/10183/17165/000685849.pdf>. Acesso em: 20 ago. 2014.

KRAMER, Heinrich; SPRENGER, James. Malleus Maleficarum: O Martelo das Feiticeiras. 11.ed.Tradução: Paulo Froes. Rio de Janeiro: Record: Rosa dos Tempos, 1995.

LOPES JR., Aury. Direito Processual Penal. 11.ed. São Paulo: Saraiva, 2014.

LUHMANN, Niklas. Sociologia do Direito I. Tradução: Gustavo Bayer. Rio de Janeiro: Tempo Brasileiro, 1983.

LULU Santos. Como Uma Onda "Ao Vivo". Disponível em:

<https://www.youtube.com/watch?v=1mSFe5WzDec>. Acesso em: 3 abr. 2014.

LYOTARD, J. F. A Condição pós-Moderna. Tradução: Ricardo Corrêa Barbosa. Rio de Janeiro: José Olympio, 2011.

LYRA FILHO, Roberto. O que é Direito. 11ª ed. São Paulo: Brasiliense, 1982.

(Coleção Primeiros Passos)

MAGALDI, Sábato. Panorama do Teatro Brasileiro. São Paulo: Global, 1998.

MORAIS DA ROSA, Alexandre. Kafka no processo e na colônia penal. In: LENIO Luiz Streck; TRINDADE, André Karam (Orgs.). Direito e Literatura. São Paulo: Atlas, 2013. p. 9-13.

NIETZCHE, Friedrich. A origem da Tragédia proveniente do espírito da música. Tradução e Notas: Erwin Theodor. São Paulo:Cupolo, 2006. Versão para Ebook. Disponível em: 〈http://www.ebooksbrasil.org/adobeebook/tragedia.pdf〉. Acesso em: 15 ago. 2014. 
PRADO, Daniel Nicory do. Autos da Barca do Inferno: o discurso narrativo dos participantes da prisão em flagrante. 2009. 128 f. Dissertação (Mestrado em Direito Público) - Universidade Federal da Bahia, Salvador, 2009. Disponível em: <https://repositorio.ufba.br/ri/bitstream/ri/10786/1/Prado.pdf>. Acesso em: 14 ago. 2014.

SANTOS, Juarez Cirino dos. Direito Penal: Parte Geral. 3. ed. Curitiba: ICPC; Lumen Juris, 2008.

SARTRE, Jean-Paul. Esboço para uma teoria das emoções. Tradução: Paulo Neves. Porto Alegre: L\&PM, 2011.

SENNETT, Richard. O Declínio do Homem Público: as tiranias da intimidade. Tradução: Lygia Araújo Watanabe. São Paulo: Companhia das Letras, 1998.

STRECK, Lenio Luiz. Tribunal do Júri: Símbolos e Rituais. Porto Alegre: Livraria do Advogado,1993.

2013.

.; KARAM TRINDADE, André (Orgs.). Direito e Literatura. São Paulo: Atlas,

SUASSUNA, Ariano. Após 10 anos afastado da literatura, o autor de "Auto da

Compadecida" está escrevendo novo livro. Folha de São Paulo, São Paulo, 26 out.

1991. Entrevista. Disponível em:

<http://almanaque.folha.uol.com.br/leituras_16jun00.htm>. Acesso em: 8 ago. 2014.

Arte como Missão. Aula-espetáculo realizada no Teatro Castro Alves,

Salvador, em 16 jul. 2014.

Auto da Compadecida. 11ª. Ed. Rio de Janeiro: Livraria AGIR, 1975.

. O Movimento Regionalista e o Armorial. Folha de São Paulo, São Paulo,

2000. Disponível em: <http://www1.folha.uol.com.br/fsp/ilustrad/fq0409200022.htm>. Acesso em: 16 ago. 2014.

TAVARES, Braulio. ABC de Ariano Suassuna. 2. Ed ${ }^{\mathrm{a}}$.Rio de Janeiro: Jose Olympio, 2007.

WARAT, Luis Alberto. A rua grita Dionísio: Direito Humanos da Alteridade, Surrealismo e Cartografia. Tradução e organização: Vivian Alves de Assis, Júlio Cesar Marcellino Jr. e Alexandre Morais da Rosa. Rio de Janeiro: Lumen Juris, 2010. 